\title{
Nomenclatural corrections in calicioid fungi
}

\section{Tuovila, Hanna}

2013-01

Tuovila , H , Rikkinen , J \& Huhtinen , S 2013 , ' Nomenclatural corrections in calicioid fungi ' , Karstenia , vol. 52 , no. 2 , pp. 73-74 .

http://hdl.handle.net/10138/309664

unspecified

publishedVersion

Downloaded from Helda, University of Helsinki institutional repository.

This is an electronic reprint of the original article.

This reprint may differ from the original in pagination and typographic detail.

Please cite the original version. 


\title{
Nomenclatural corrections in calicioid fungi
}

\author{
HANNA TUOVILA, JOUKO RIKKINEN and SEPPO HUHTINEN
}

TUOVILA, H., RIKKINEN, J. \& HUHTINEN, S. 2012: Nomenclatural corrections in calicioid fungi. - Karstenia 52:73-74. HELSINKI. ISSN 0453-3402.

The nomenclature and typification of some calicioid fungi in the genera Chaenothecopsis and Brucea are corrected. Chaenothecopsis oregana is reinstated with a new lectotype (holotype lost), while $C$. zebrina is reduced to its synonymy. Brucea is a later homonym and is therefore replaced by the new generic name Bruceomyces. A new combination $B$. castoris is introduced.

Key words: Mycocaliciales, Chaenothecopsis, Brucea, Bruceomyces

Hanna Tuovila \& Jouko Rikkinen, Department of Biological and Environmental Sciences, University of Helsinki, PO Box 65, FI-00014 Helsinki. Finland; e-mails: hanna. tuovila@helsinki.fi,jouko.rikkinen@helsinki.fi

Seppo Huhtinen, Herbarium, University of Turku, FI-20014 Turku, Finland; e-mail: sephuh@utu.fi

As noted by Tuovila et al. (2011), in the holotype specimen of Chaenothecopsis oregana Rikkinen no ascomata of the named species are preserved, but the type still includes those of another, previously undescribed taxon. In other words, the present "holotype" material does not correspond with the species description of $C$. oregana (Rikkinen 2003). For this reason Tuovila et al. (2011) proposed to discard the species epithet oregana and described both Chaenothecopsis species in question as new. Accordingly, the species present in the original holotype of $C$. oregana was described as Chaenothecopsis diabolica Rikkinen \& Tuovila, and the species corresponding to the original description as Chaenothecopsis zebrina Rikkinen \& Tuovila. We have since been informed that this is not nomenclaturally possible. In a mixed type specimen lectotypification should be made to preserve the name with an element corresponding most nearly to the original diagnosis (Art. 9.14)

The holotype material has been studied once again and it definitely no longer contains the ele- ment originally linked to the epithet "oregana". However, there was some hope that the whole type material was not lost. The original diagnosis was published with two photographs of the holotype and the photographed ascocarps (Rikkinen 2003, Fig. 13) have been kept separately. They were recently found and restudied but unfortunately they also represent the other element of type material ( $C$. diabolica). However, the photograph of ascospores (Rikkinen 2003, Fig. 14) clearly shows a spore form and size range that is typical for $C$. oregana, not for $C$. diabolica. It is the only original element left of the holotype but cannot be designated as the lectotype in presence of paratypes (Art. 9.12). By selecting a paratype of Chaenothecopsis oregana as the lectotype, we reduce $C$. zebrina to a synonym of this species. Because the holotype and paratypes of $C$. zebrina correspond to the original description of $C$. oregana, the more detailed description of $C$. zebrina should be consulted when specimens of C. oregana are identified. 
Chaenothecopsis oregana Rikkinen, Annales Botanici Fennici 40: 448. 2003.

Lectotype (designated here): U.S.A. Oregon. Lincoln County, H.B. Van Duzer Forest Corridor Wayside, $45^{\circ} 02.2^{\prime} \mathrm{N}, 123^{\circ} 48.6^{\prime} \mathrm{W}$, elev. $150 \mathrm{~m}$; on exudate and lignum in beaver scar at trunk base of living Tsuga heterophylla, 1998 Rikkinen $98333(\mathrm{H})$

$=$ Chaenothecopsis zebrina Rikkinen \& Tuovila in Tuovila, Larsson \& Rikkinen, Karstenia 51: 42. 2012, nom. illeg. (Art. 9.14).

Rikkinen $98010 a(\mathrm{H})$ and Rikkinen $98010 b(\mathrm{H})$ of the paratypes original paratypes of $C$. oregana have been confiremed to present this species. In the original diagnosis of $C$. oregana, the holotype was erroneously cited with two sets of coordinates and with two different elevations a.s.l. However, the holotype is a single collection (Rikkinen 98363) with the following, corrected data: $44.0^{\circ} 38.47^{\prime} \mathrm{N}, 123^{\circ} 18.79^{\prime} \mathrm{W}$, elev. $180-185 \mathrm{~m}$.

Also another calicioid fungus, Brucea castoris Rikkinen was described in Rikkinen (2003). As it was later revealed that the name Brucea had previously been reserved for the angiosperm genus Brucea J. F. Mill. (Icon. Anim. Pl. t. 25. 1779-1780 [nom. cons.]), the new genus name Bruceomyces is here introduced for the enigmatic fungus.

\section{Bruceomyces Rikkinen, nom. nov.}

Based on: Brucea Rikkinen, Annales Botanici Fennici 40: 444. 2003, nom. illeg. (non Brucea J. F. Mill. 1779-1780).

MycoBank no.: MB 803286

The single species of the genus is combined to the genus as follows:

Bruceomyces castoris (Rikkinen)

Rikkinen, comb. nova

MycoBank no.: MB 803287

= Brucea castoris Rikkinen, Annales Botanici

Fennici 40: 444. 2003.
Holotype: U.S.A. Oregon. Polk County, Little Sinks Research Natural Area, $44^{\circ} 50.3^{\prime} \mathrm{N}, 123^{\circ}$ 26.4'W, elev. $200 \mathrm{~m}$, on resin and resin-soaked lignum of Abies grandis, 1998 Rikkinen 98010 ( $\mathrm{H}$, isotypes OSC, UPS).

Acknowledgements: We kindly thank Teuvo Ahti for bringing the errors concerning Chaenothecopis oregana to our attention and for valuable help in preparing this article. Ernest Emmett is thanked for linguistic corrections.

\section{References}

Mcneill, J., Barrie, F.R., Buck, W.R:, Demoulin, V., Greuter, W., Hawksworth, D.L., Herendeen, P.S., Knapp, S., Marhold, K., Prado, J., Prud'homme van Reine, W.F., Smith, G.F., Wiersema, J.H. \& Turland, N.J. 2012: International Code of Nomenclature for algae, fungi, and plants (Melbourne Code). - Regnum Vegetabile 154. A.R.G. Gantner Verlag KG.

Rikkinen, J. 2003: New resinicolous ascomycetes from beaver scars in Western North America. - Annales Botanici Fennici 40: 443-450.

Tuovila, H., Larsson, P. \& Rikkinen, J. 2011: Three resinicolous North American species of Mycocaliciales in Europe with a re-evaluation of Chaenothecopsis oregana Rikkinen. - Karstenia 51: 37-49. 